Article

\title{
An Adaptive Neuro-Fuzzy Inference Model to Predict Punching Shear Strength of Flat Concrete Slabs
}

\author{
Mohammed A. Mashrei *(D) and Alaa M. Mahdi \\ Department of Civil Engineering, Thi-Qar University, Nasiriya 00964, Iraq; alaacivil155@gmail.com \\ * Correspondence: Muhammad-a@utq.edu.iq or mohamaw@gmail.com; Tel.: +964-783-144-1125
}

Received: 7 December 2018; Accepted: 20 February 2019; Published: 25 February 2019

\begin{abstract}
An adaptive neuro-fuzzy inference system (ANFIS)-based model was developed to predict the punching shear strength of flat concrete slabs without shear reinforcement. The model was developed using a database collected from 207 experiments available in the existing literature. Five key input parameters were used to build the model, which were slab effective depth, concrete strength, reinforcement ratio, yield tensile strength of reinforcement, and width of square loaded area. The output parameter of the model was punching shear strength. The results from the adaptive neural fuzzy inference model were compared to those from the simplified punching shear equations of ACI, BS-8110, Model Code 2010, Euro-Code 2, and also experimental results. The root mean square error (RMSE) and the correlation coefficient $(R)$ were used as evaluation criteria. Parametric studies were presented using ANFIS to assess the effect of each input parameter on the punching shear strength and to compare ANFIS results to those from the equations proposed in commonly used codes. The results showed that the ANFIS model is simple and provided the most accurate predictions of the punching shear strength of two-way flat concrete slabs without shear reinforcement.
\end{abstract}

Keywords: concrete; punching shear; two-way flat slabs; ANFIS

\section{Introduction}

Generally, the contact surfaces between columns and slabs are very small in flab slab systems, and therefore high stresses are concentrated in the connections area. A punching shear failure may occur if the stresses exceed the limitations. This failure is brittle and may occur unexpectedly. To avoid this type of failure, various construction methods have been developed [1].

In the design and analysis of two-way flat slabs without shear reinforcement, the punching shear strength is an important parameter. Much research has been conducted throughout the current century, and the key variables affecting the punching shear strength of slabs have been identified [2-5]. Most of the research has been concerned with the generation of experimental data and the development of empirical equations in addition to the equations proposed by ACI 318-14 [6], BS-8110-97 [7], Model Code 2010 [8], and Euro-Code 2 [9]. However, the subject still needs further study to understand the complexity of punching shear behavior and to develop better prediction tools.

Fuzzy logic (FL) and neural network (NN) techniques have been widely used in civil engineering applications over the last two decades. In this study, an alternative model was developed within the framework of an adaptive neuro-fuzzy interface system (ANFIS) to predict the punching shear of two-way slabs without shear reinforcement. This model was developed using a large database (207 experimental results) compiled from 17 scientific studies. The predictions from this model were compared to those from the equations proposed in commonly used codes. 


\section{ANFIS: Literature Review}

The solution of problems associated with engineering systems requires the use of several different disciplines implementing different methods of modeling and analysis. For a complex engineering system, often a physics-based mathematical model is used, which is extremely difficult to formulate. For such a system, several other approaches (neural networks, fuzzy inference systems, etc.) under the rubric of "soft computing" provide a useful alternative. Soft computing models are becoming popular and have been of increasing interest during the last three decades. This approach is based on human reasoning and learning and uses the human tolerance for uncertainty and imprecision and fuzziness in the decision-making processes [10]. Recently, artificial neural networks (ANNs) and ANFIS have been used extensively for various civil engineering applications in construction management, building materials, hydraulics, structural engineering, geotechnical and transportation engineering, etc. Here, a selected few recent works in the area related to our subject are presented. Kasperkiewicz et al. [11] developed an ANN to predict the compressive strength of high-performance concrete mixes. Takagi and Sugeno [12] developed a fuzzy inference system (FIS) model and applied it to modeling and controlling concepts. Topçu and Saridemir [13] applied ANN and FL to predict rubberized mortar properties. Bilgehan [14] used ANFIS and NN models to determine the critical buckling load. Tesfamariam and Najjaran [15] developed an ANFIS model to estimate the concrete strength of a given mix proportion based on existing datasets. Akbulut et al. [16] used ANFIS to predict the shear modulus and damping coefficient of sand and rubber mixtures. Inan et al. [17] used an adaptive neuro-fuzzy system to simulate nonlinear mapping in the sulphate expansion of Portland cement (PC) mortar. Experimental data that had previously been collected for various parameters were treated in the analysis. Fonseca et al. [18] developed a neuro-fuzzy model to classify and to predict the behavior of steel beams under concentrated loads. Wang and Elhag [19] applied ANFIS to assess bridge risk based on multiple bridge maintenance projects. Batenia and Jeng [20] used ANFIS to investigate the characteristics of a scour hole that develops around a group of piles in a well-defined field situation and to determine the parameters that control the scour hole. Mashrei [21] developed an ANFIS model to predict the shear strength of concrete beams reinforced with fiber-reinforced polymer (FRP) bars. Bilgehan and Kurtoglu [22] applied ANFIS to predict the moment capacities of reinforced concrete (RC) slabs exposed to fire. Mansouri et al. [23] investigated the ability of radial basis neural networks and ANFIS methods in the prediction of ultimate strength and strain of concrete cylinders confined with FRP sheets. Naderpour and Mirrashid [24] used ANFIS to determine the shear strength of RC beams with shear reinforcement. Basarir et al. [25] used an ANFIS model to predict the uniaxial compressive strength of cemented backfill.

\section{Existing Equations Used for Two-Way Flat Slabs}

For the design of a two-way flat slab-column connection, the shear stress is usually assumed to be a function of strength of concrete and the geometric parameters of the slab and column. The critical section for checking punching shear in slabs is usually situated between 0.5 and 2 times the effective depth from the edge of the load or reaction. Many empirical equations have been published to estimate the punching shear strength of two-way slabs, such as the equations proposed in $\mathrm{ACI}$ 318-14, BS-8110-97, Model-Code-2010, and Euro-Code 2 [6-9].

\subsection{ACI 318-14 Building Code Equations}

A set of simple equations were proposed in the ACI 318-14 code to calculate the shear strength provided by concrete. The control perimeter is half of the effective depth of the slab $(0.5 d)$ from the loaded area for punching shear stress. ACI 318-14 requires that the nominal shear resistance for slabs without shear reinforcement be approximated as the smallest value of $V_{n}$ calculated from the following expressions:

$$
V_{n}=0.083\left(2+\frac{4}{\beta_{c}}\right) \lambda \sqrt{f_{c}^{\prime}} b_{o} d,
$$




$$
\begin{gathered}
V_{n}=0.083\left(\alpha_{s} \frac{d}{b_{o}}+2\right) \lambda \sqrt{f_{c}^{\prime}} b_{o} d, \\
V_{n}=0.33 \lambda \sqrt{f_{c}^{\prime}} b_{o} d,
\end{gathered}
$$

where $V_{n}$ is the shear strength in $\mathrm{N}, b_{o}$ is the perimeter of the critical section in mm, $d$ is the effective depth of slab in $\mathrm{mm}$, and $\lambda=1.0$ for normal weight concrete and 0.75 for all lightweight concrete. Otherwise, $\lambda$ is determined based on volumetric proportions of lightweight and normal weight aggregates, but does not exceed 0.85 . Here, $\alpha_{s}=40$ for interior columns, 30 for edge columns, and 20 for corner columns; $\beta_{c}$ is the ratio of the longer to the shorter dimension of the loaded area; and $f_{c}^{\prime}$ is the cylinder compressive strength of concrete in MPa.

\subsection{Model Code 2010}

The nominal punching shear strength is assumed to be proportional to $\left(f_{c k}\right)^{1 / 3}$ in Model Code 2010. The influences of the slab depth and steel reinforcement are also considered in this model. The punching strength according to Model Code 2010 is expressed by

$$
V_{n}=0.18 b_{0} d \times \xi \times \sqrt[3]{100 \times \rho \times f_{c k}},
$$

where $f_{c k}$ is the characteristic cylinder compressive strength in MPa, $\xi=1+(200 / d)^{1 / 2}$ is a size effect coefficient, $d$ is the slab effective depth in $\mathrm{mm}, \rho$ is the ratio of flexure reinforcement, and $b_{0}$ is the length of the control perimeter at $2 d$ from the column face in $\mathrm{mm}$.

\subsection{British Code: BS-8110-97}

The British Code provisions proposed the following expression to estimate the shear strength of slabs:

$$
V_{n}=0.79(100 \times \rho)^{\frac{1}{3}}(400 / d)^{\frac{1}{4}} \times\left(\frac{f_{c u}}{25}\right)^{\frac{1}{3}} \frac{b_{o} d}{1.25}
$$

where $f_{c u}$ is the cubic compressive strength in MPa. It should be noted that in the British Code, the critical section for shear is considered to be $1.5 d$ from the face of the column. All terms were defined previously.

\subsection{Euro-Code 2 (EC2)}

The Euro-Code 2 (EC2) recommends that the punching shear resistance be expressed as proportional to $\left(f_{c k}\right)^{\frac{1}{3}}$, where $f_{c k}$ is the compressive strength of concrete. In EC2, the influences of slab depth and steel reinforcement are also considered. The punching shear resistance according to EC2 may be calculated as

$$
V_{n}=\frac{0.18}{\gamma_{c}} K b_{o} d\left(1000 \times \rho \times f_{c k}\right)^{\frac{1}{3}} \frac{2 d}{a_{c r t}} \geq 0.035 k^{\frac{3}{2}} f_{c k}{ }^{\frac{1}{2}} \frac{2 d}{a_{c r t}} b_{o} d,
$$

where $\gamma_{c}$ is the material resistance factor for concrete $=1.5, d$ is the effective depth, $K=1+\sqrt{200 / d} \leq 2$ is the size factor of the effective depth, $\rho$ is the flexural reinforcement ratio $\leq 2 \%, f_{c k}$ is the cylinder compressive strength of concrete, and $a_{c r t}$ is the distance from column face to the control perimeter.

It should be noted that some codes do not consider the size effect in estimates of the punching shear strength of slabs, such as ACI 318-14, while some common codes, such as Model-Code-2010 and Euro-Code 2, consider the size effect in the design of slabs for punching shear in the same form as presented in Equations (4) and (6). Deferent forms of the size effect have been presented by many researchers to consider the effect of this factor on punching shear strength: More details about the size effect can be found in References [26-30]. 


\section{ANFIS: An Introduction}

Recently, a fundamental change has occurred in the methodology of empirical analysis. Because of the nonlinearity and high degree of uncertainty associated with structural behavior, traditional mathematical models are difficult to develop. As an alternative, FIS- and ANN-based models (belonging to "soft computing") are being used for many civil engineering problems. Nowadays, ANNs have been accepted as very useful tools for modeling nonlinear systems and are being widely used. FIS has emerged as a useful tool to represent and analyze complex systems [31-33]. Each method has its own advantages and disadvantages. Whereas in FIS there is no systematic procedure for designing a fuzzy controller, ANNs have the ability to map the input and output datasets through supervised learning and a self-organized structure. For this reason, it was proposed to combine an FIS and ANN together to get ANFIS, which enhances the efficiency of the systems and the modeling of problems using available data. ANFIS is thus an integration of an ANN and an FIS and uses basic FIS rules and the ANN network architecture to update system parameters using existing input and output pairs. ANFIS was first introduced by Jang [34]. In both an ANN and FIS, input parameters pass through the input layer using an input membership function, and the output parameters are seen in the output layer using output membership functions. In this method, the parameters are changed until an optimal solution is reached using a learning algorithm. A basic flow diagram of computations in ANFIS is illustrated in Figure 1. Several fuzzy inference systems have been developed by different researchers [12,35-38], who commonly use Mamdani-type and Takagi-Sugeno-type systems. In this study, a Takagi-Sugeno-type system was used.

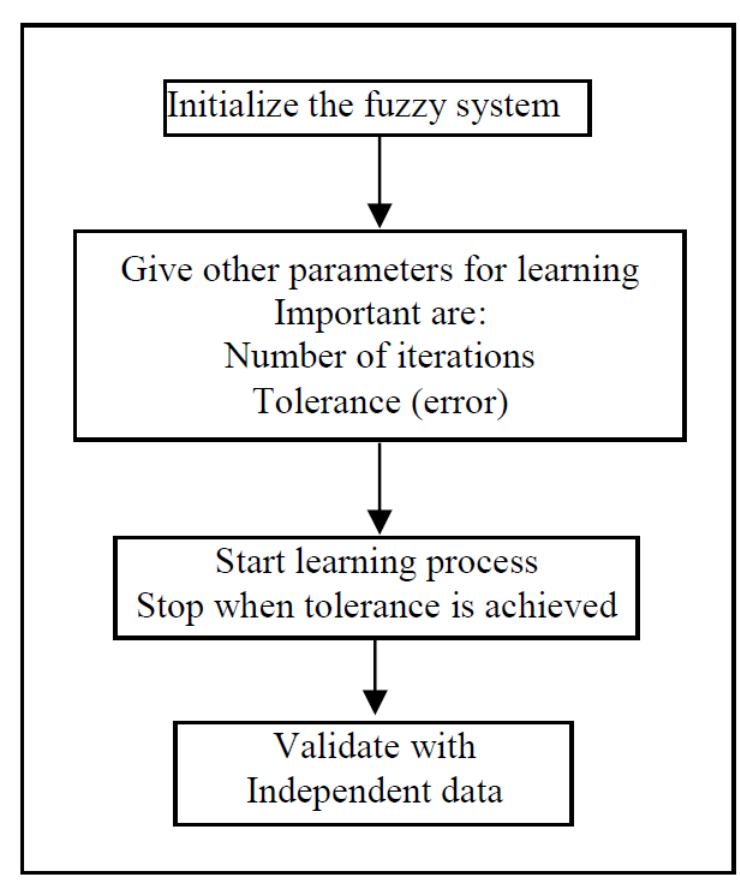

Figure 1. The basic flow diagram for computations in an adaptive neuro-fuzzy interface system (ANFIS).

\section{ANFIS: This Study}

In this study, an ANFIS model was developed using MATLAB R2013a [39] with five input parameters: The slab effective depth $(d)$, compressive strength of concrete $\left(f_{c}^{\prime}\right)$, reinforcement ratio $(\rho)$, yield strength of reinforcement $\left(f_{y}\right)$, and width of square loaded area $(c)$. The output variable is punching shear strength of a two-way slab $(V)$. A set of 207 experimental data points, collected from several sources [40-56], was used to develop the model. The experimental data were randomly divided into two sets: The first one, with 164 data points, was used for training the model, and the 
second one, with 43 data points, was used for testing. A subtractive clustering technique produced by Chiu [57] was used to generate the ANFIS model with the (genfis2) function in MATLAB. Genfis2 is used to help in the creation of the initial set of membership functions for sets of input and output data. Genfis2 preforms this model by extracting a set of rules. The rule extraction method first uses the subclust function to determine the number of rules and antecedent membership functions. The type and the number of membership functions were evaluated when the training and testing datasets were giving good predictions according to the root mean square error (RMSE). After experimenting with different learning algorithms with a number of different epochs, the best correlations were found through a hybrid learning algorithm (a combination of least squares and back-propagation algorithms for membership function parameter estimations). The final errors of the model for training and testing were 0.45 and 0.52 , respectively, and were achieved after 200 epochs. The structure of the ANFIS model is illustrated in Figure 2. In the model, 10 of the Gaussian membership functions (gaussmf) are selected for each input, and 10 rules define the relationship between inputs and outputs. A Gaussian membership function has two parameters: $c$, responsible for its center, and $\sigma$, responsible for its width, and the equation for this type is $[39,58]$

$$
A(x)_{\text {Gauss }}=\exp \left[-\left(\frac{x-c}{2 \sigma}\right)^{2}\right] .
$$

Readers are referred to Reference [58] for more details on this type of membership function. The numerical range of input parameters of the current study is listed in Table 1 . The data used to build the ANFIS model are summarized in Table A1 in Appendix A. After the training procedure, the model was tested using the remaining data not used for the training. Figure 3 shows the performance for training and testing datasets. Figures 4 and 5 show the matching of the experimental results with the results of the ANFIS model for both training and testing sets, respectively. Figure 6 shows a comparison between the experimental results of punching shear and the results predicted by the ANFIS model for all samples used in the model (training and testing sets). The adequacy of the developed ANFIS was evaluated by considering the coefficient of correlation $(R)$, the average and standard deviation of the ratio of predicted to experimental punching shear strength, and the root mean square error (RMSE). The equations of the statistical parameter RMSE and the coefficient of correlation $(R)$ that were used to compare the performance of each method are

$$
\begin{aligned}
& \text { RMSE }=\sqrt{\frac{\sum_{i=1}^{N}\left(V_{n e}-V_{n i}\right)^{2}}{N},} \\
& R=1-\sqrt{\frac{\sum_{i=1}^{N}\left(V_{n e}-V_{n i}\right)^{2}}{\sum_{i=1}^{N}\left(V_{n e}\right)^{2}}},
\end{aligned}
$$

where $V_{n e}$ and $V_{n i}$ are the experimental and prediction nominal punching shear strength $\left(V_{n}\right)$ of two-way flat slabs, respectively, and $N$ is the total number of samples considered.

Table 1. Range of input parameters in the database.

\begin{tabular}{cc}
\hline Parameters & Range \\
\hline The slab effective depth $(d)(\mathrm{mm})$ & $35-550$ \\
Concrete cylinder compressive strength $\left(f_{c}^{\prime}\right)(\mathrm{MPa})$ & $14.2-119$ \\
Reinforcement ratio $(\rho)(\%)$ & $0.25-5.01$ \\
Yield strength of reinforcement $\left(f_{y}\right)(\mathrm{MPa})$ & $294-720$ \\
Width of square loaded area $(c)(\mathrm{mm})$ & $80-500$ \\
\hline
\end{tabular}




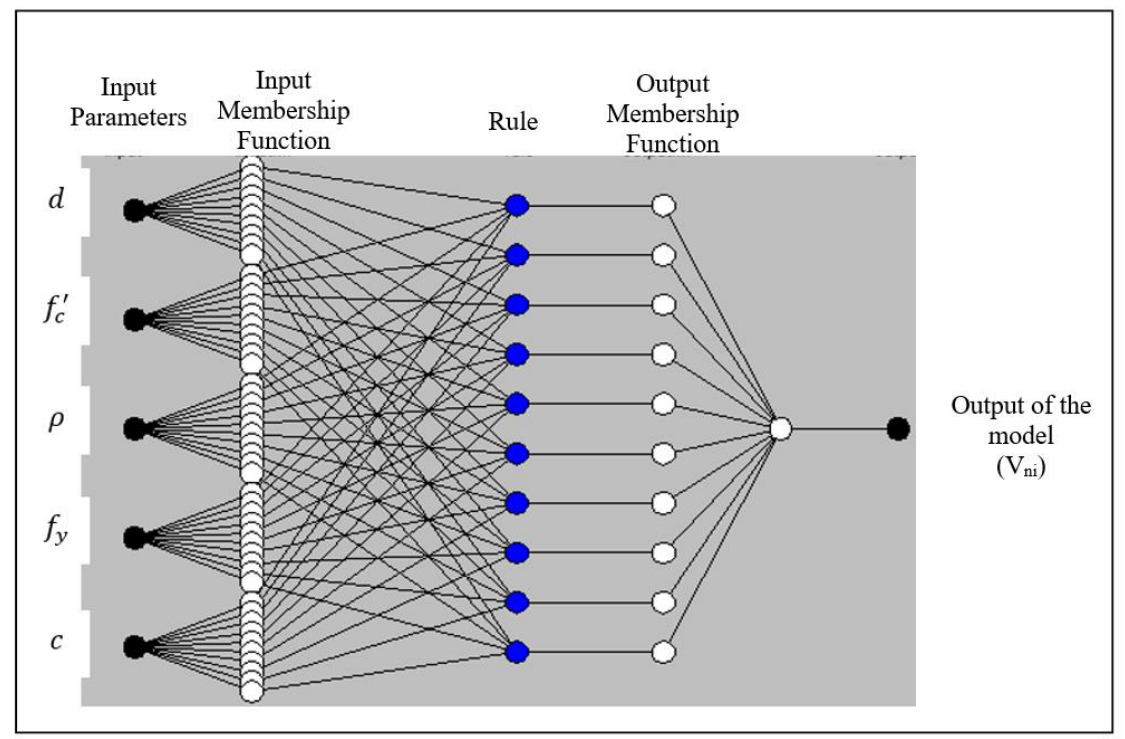

Figure 2. Network Structure of the ANFIS model.

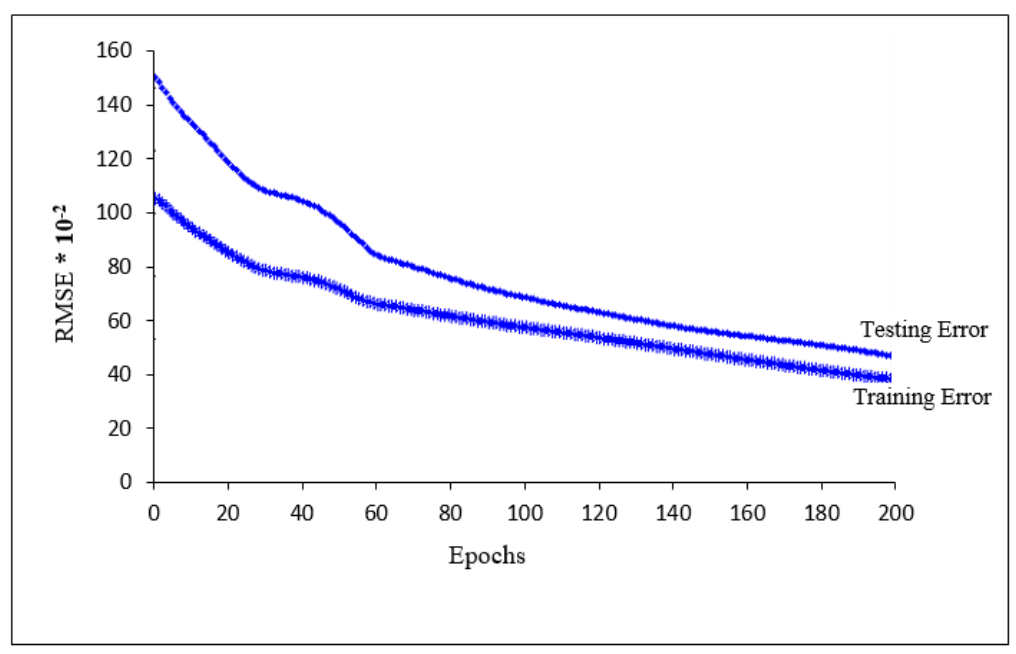

Figure 3. Convergence of the ANFIS for training and testing sets.

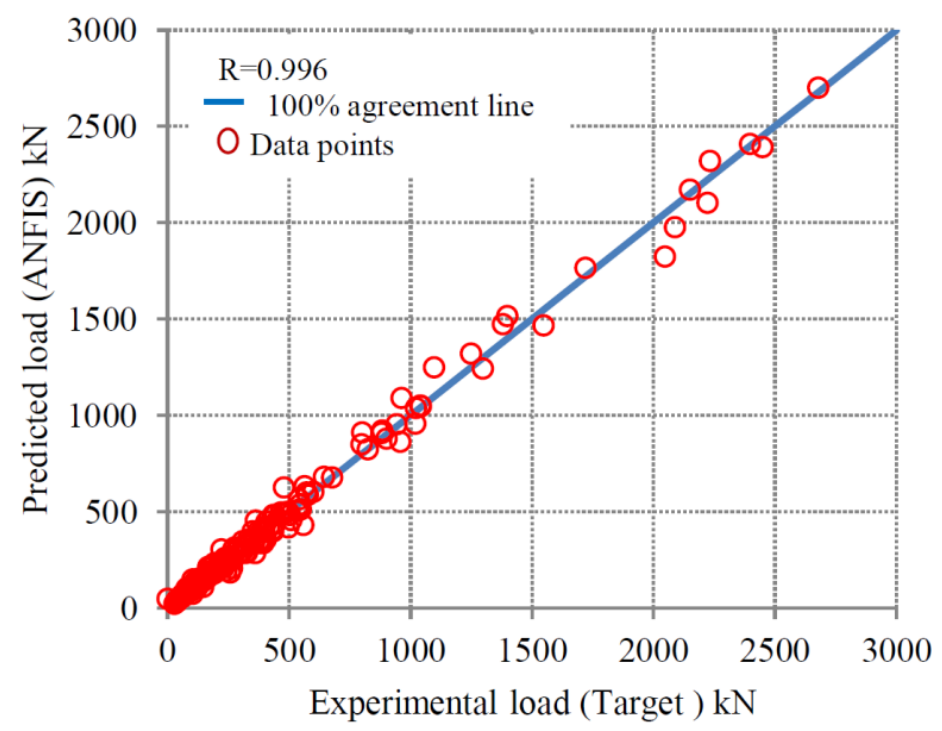

Figure 4. Experimental and predicted punching shear strength (training dataset). 


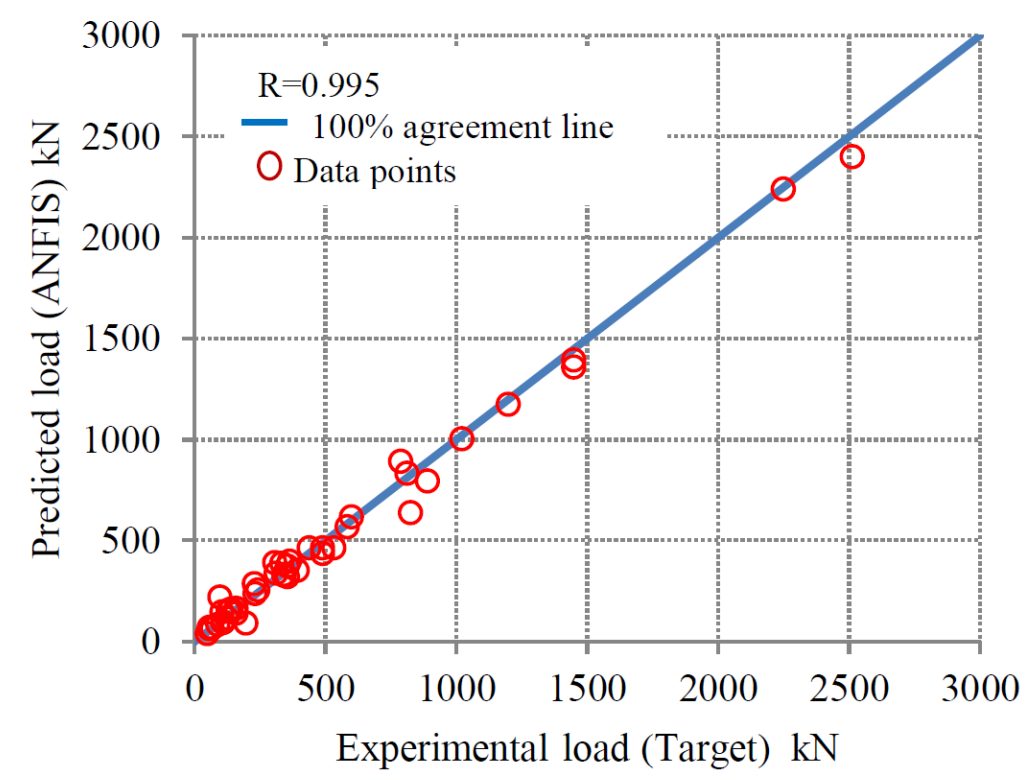

Figure 5. Experimental and predicted punching shear strength (testing dataset).

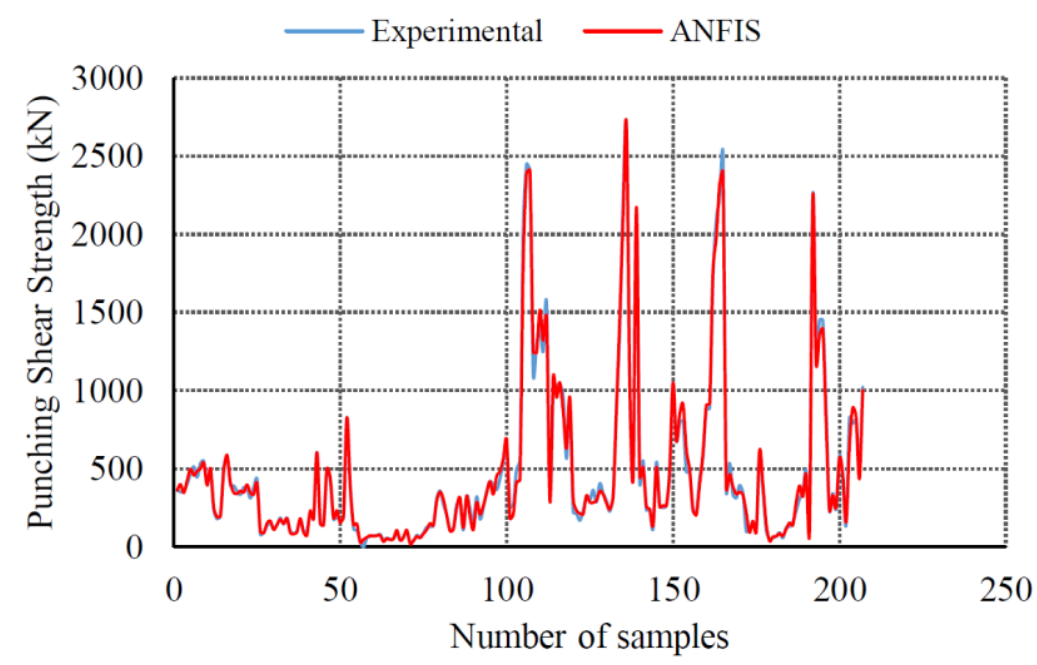

Figure 6. Experimental and predicted punching shear strength for all samples.

\section{ANFIS: Results and Comparison}

Figures 7-18 show the comparison of the results obtained from the ANFIS model, ACI-14 code, Model Code 2010, British Code, and Euro-Code 2 for both training and testing datasets. A comparison of the results of the five models was also made with the experimental results. It was noted that the results of the ANFIS model were better than the results of four design codes: However, the results from BS-8110-97 were reasonable when compared to the experimental results. Table 2 summarizes the average and standard deviation (STDEV) of the ratios of predicted punching shear strength $\left(V_{n i}\right)$ to the experimental results $\left(V_{n e}\right)$. The ANFIS model gave an average $V_{n i} / V_{n e}$ ratio for the training and test datasets of 1.0 and 1.01, respectively, and a standard deviation of 0.11 and 0.13 , respectively. These results indicate that the ANFIS model could make more reliable predictions of the punching shear strength compared to those from the four design codes. Table 3 also confirms this conclusion when comparing the correlation coefficient for all models for training, testing, and the combined datasets. The values of $0.996,0.995$, and 0.995 for the ANFIS training, testing, and combined datasets, respectively, were very close to 1.0 and higher than those of the other four design codes. Finally, the same conclusion could be made from the root mean square error, as listed in Table 3: The minimum values of the RMSE were 0.45 and 0.52 for the training and testing sets, respectively. 


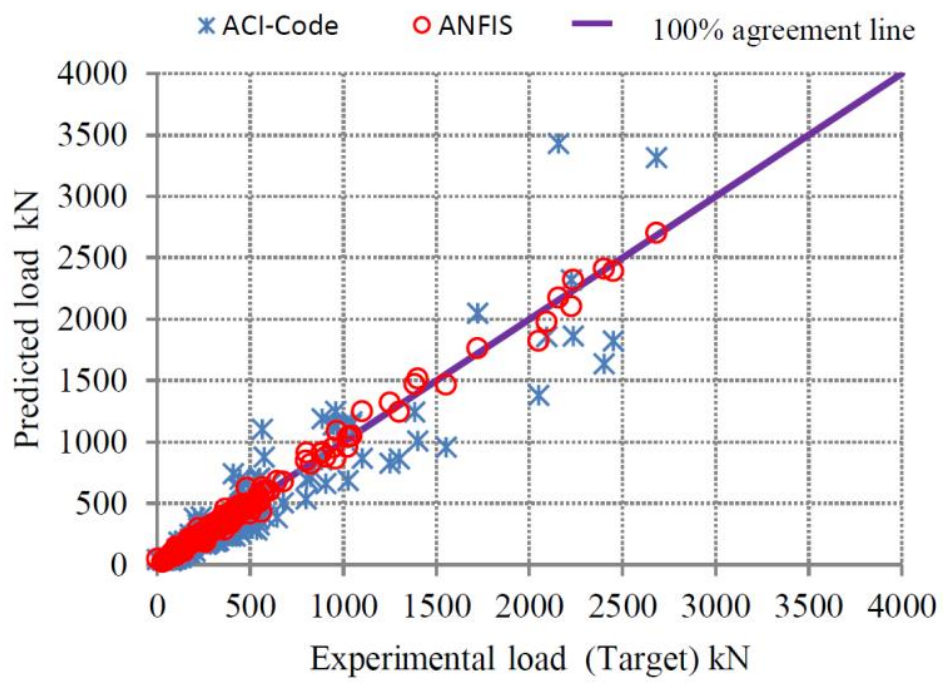

Figure 7. Experimental and predicted punching shear strength (training dataset).

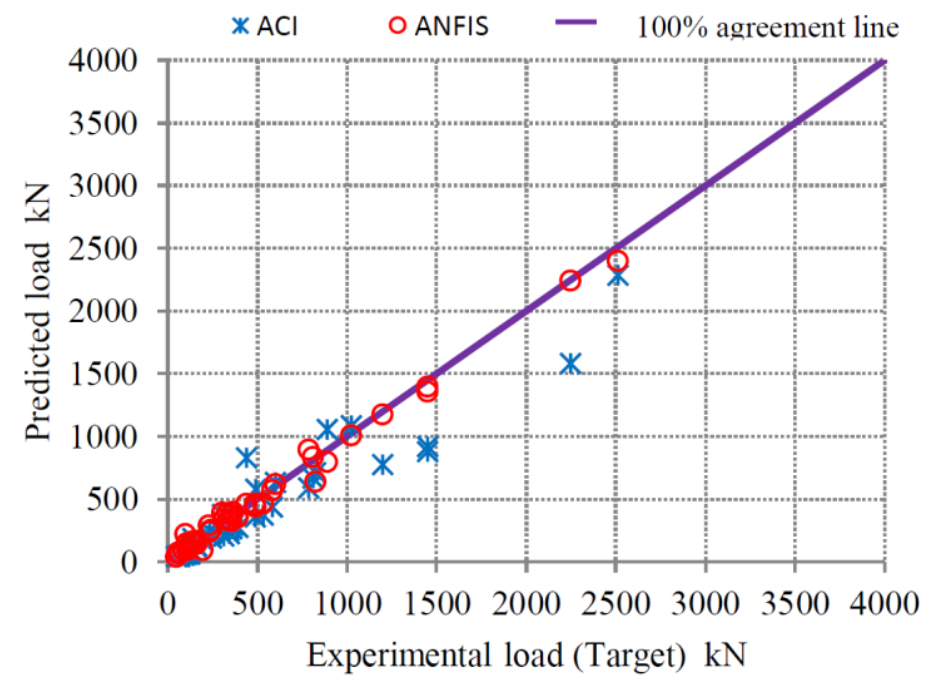

Figure 8. Experimental and predicted punching shear strength (testing dataset).

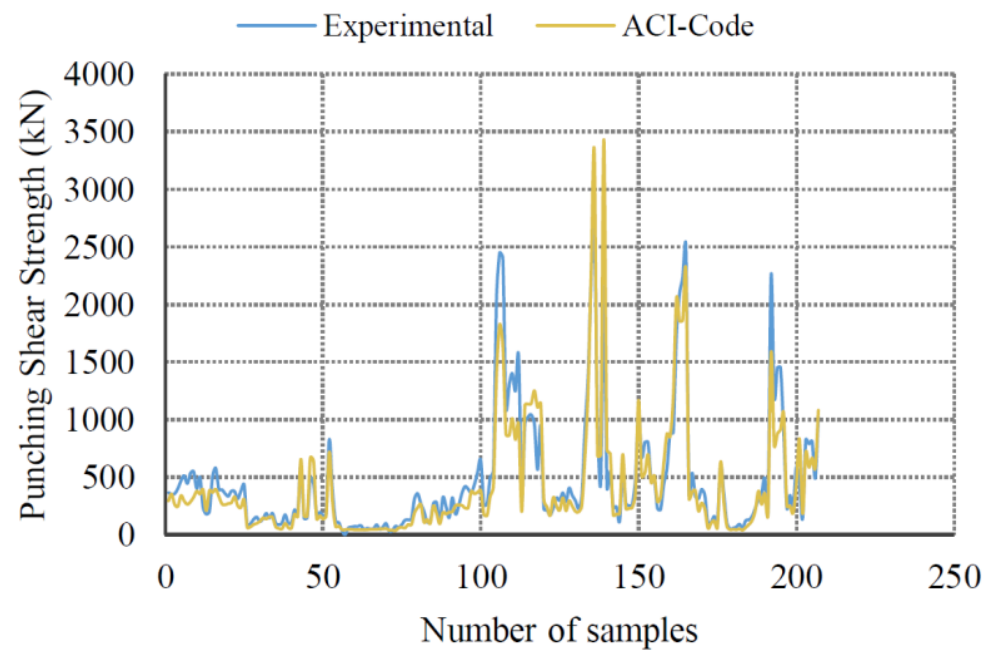

Figure 9. Experimental and predicted punching shear strength for all samples. 


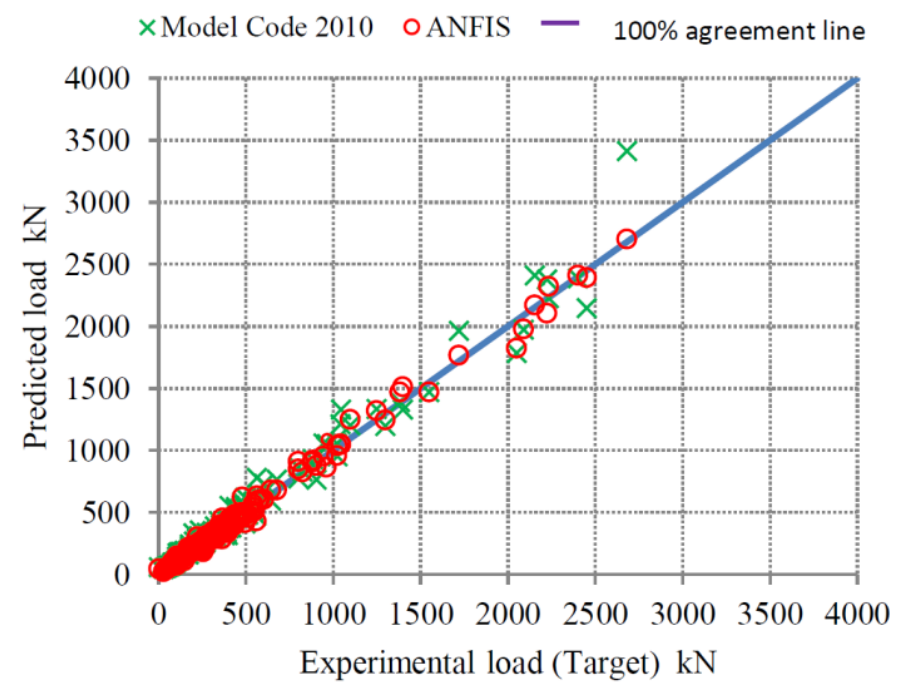

Figure 10. Experimental and predicted punching shear strength (training dataset).

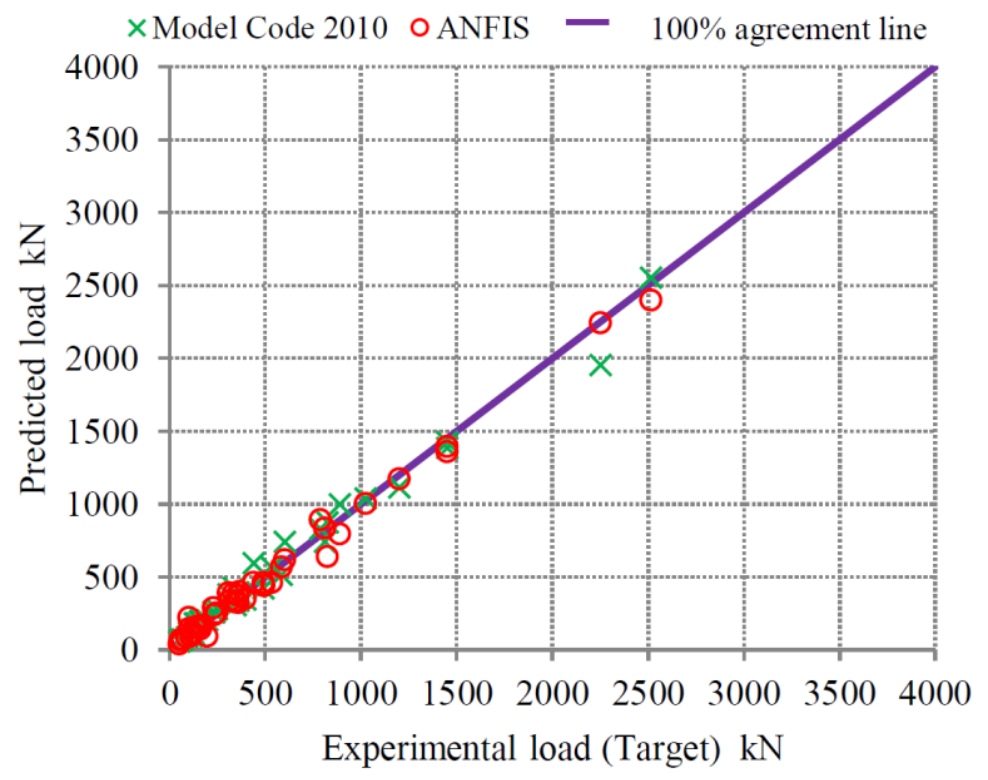

Figure 11. Experimental and predicted punching shear strength (testing dataset).

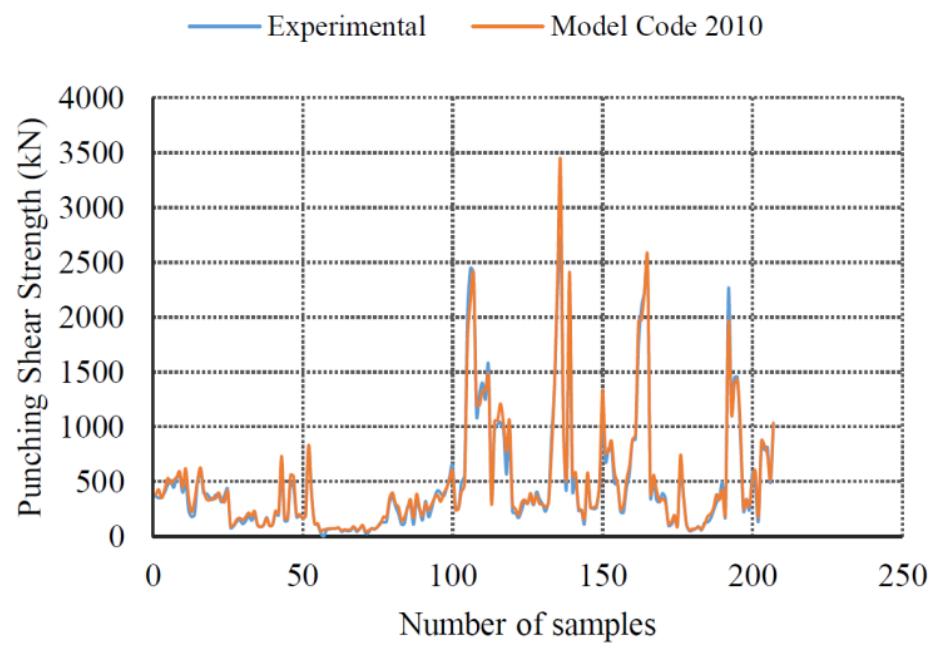

Figure 12. Experimental and predicted punching shear strength for all samples. 


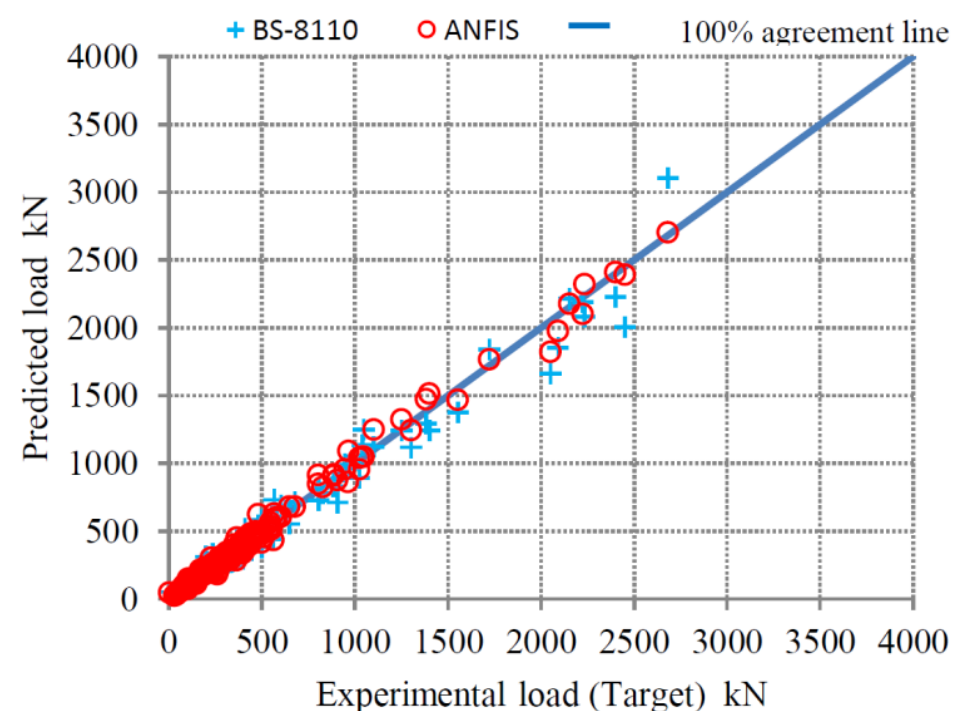

Figure 13. Experimental and predicted punching shear strength (training dataset).

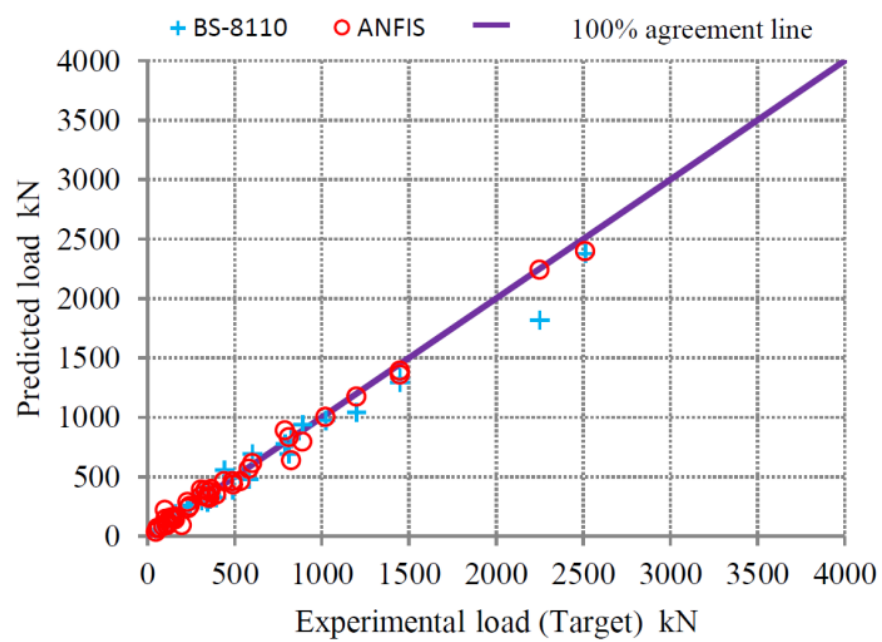

Figure 14. Experimental and predicted punching shear strength (testing dataset).

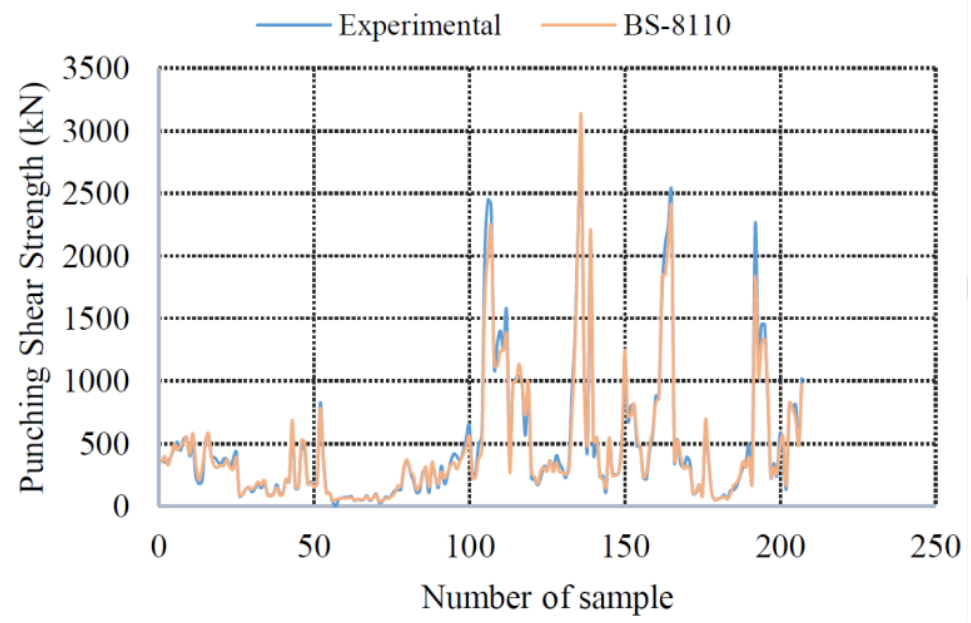

Figure 15. Experimental and predicted punching shear strength for all samples. 


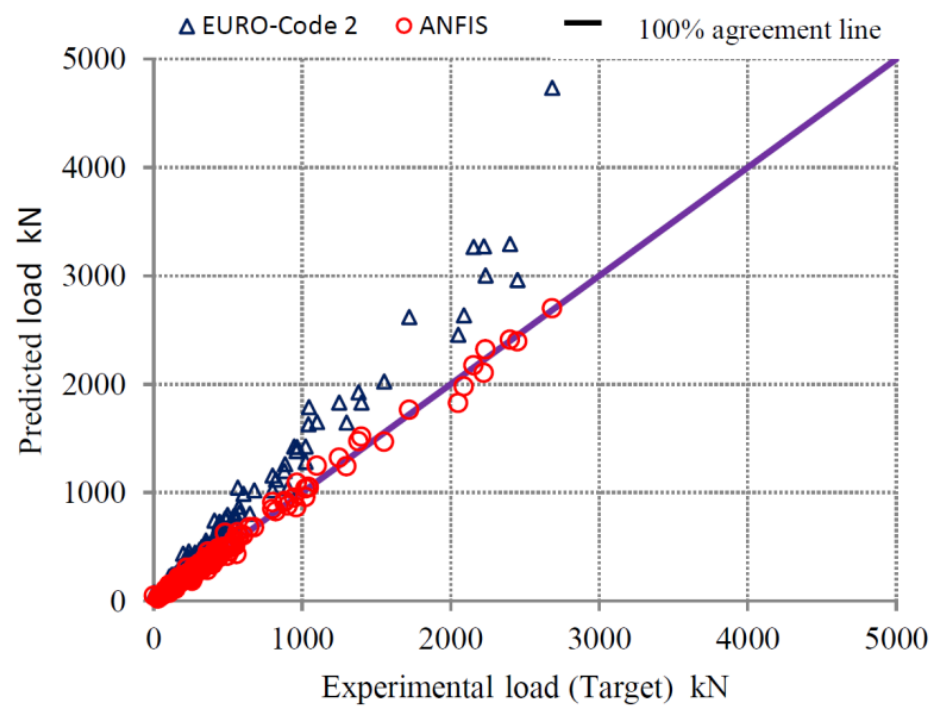

Figure 16. Experimental and predicted punching shear strength (training dataset).

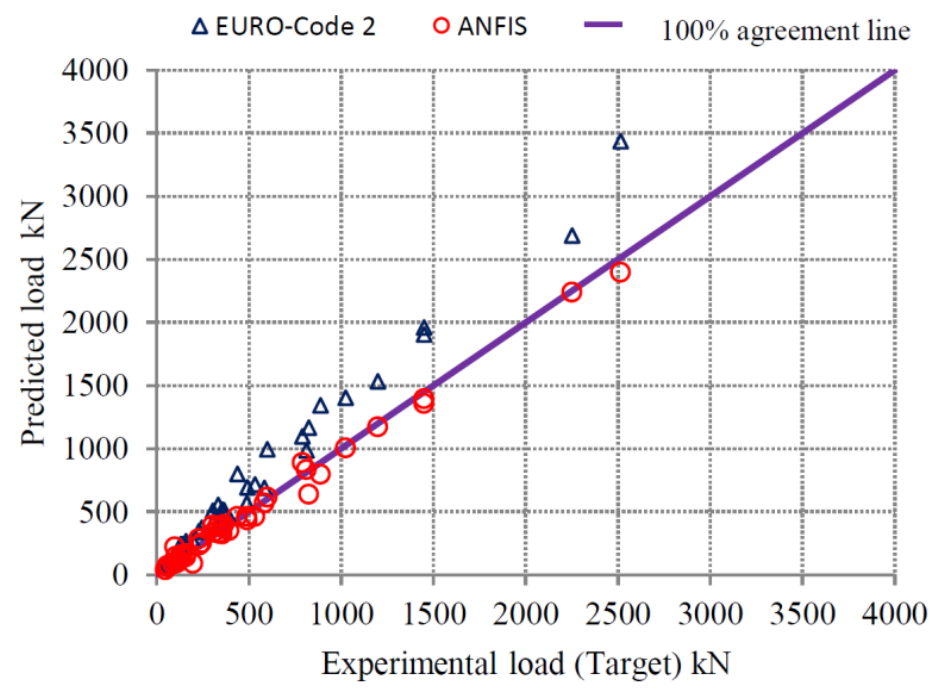

Figure 17. Experimental and predicted punching shear strength (testing dataset).

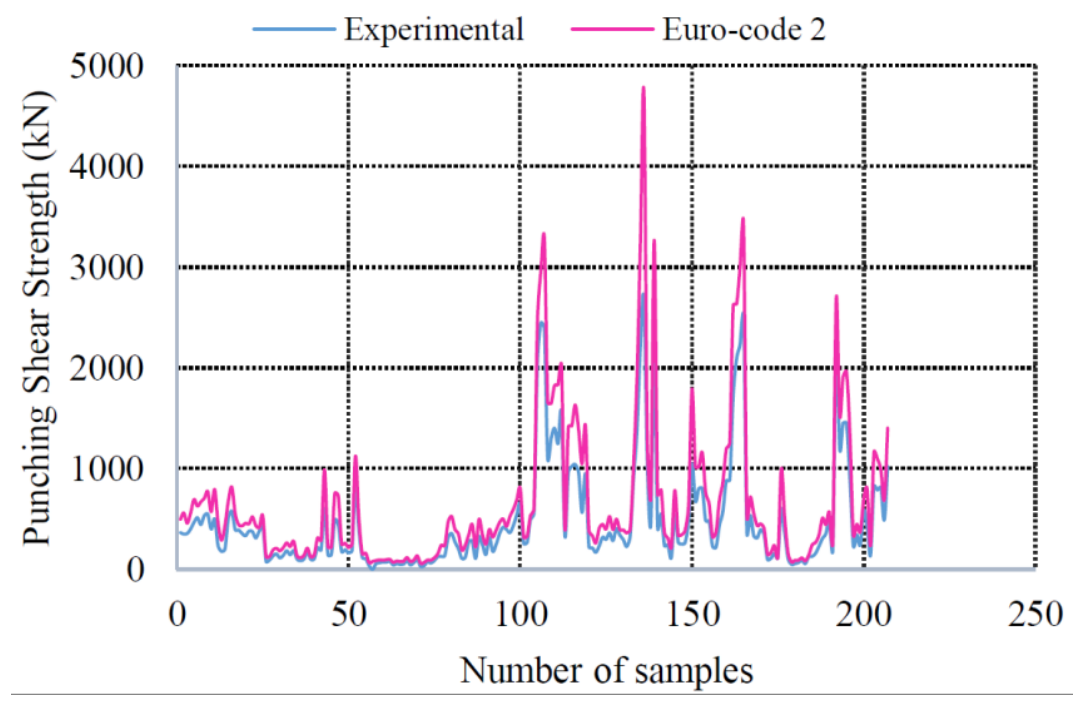

Figure 18. Experimental and predicted punching shear strength for all samples. 
Table 2. Comparison of punching shear between the experimental and predicted results for the training and testing sets. STDEV: Standard deviation.

\begin{tabular}{cccccccccccc}
\hline & & \multicolumn{4}{c}{ Average of $V_{n i} / V_{n e}$} & \multicolumn{4}{c}{ STDEV of $V_{n i} / V_{n e}$} \\
\cline { 2 - 13 } Specimens & No. & ANFIS & $\begin{array}{c}\text { ACI-14 } \\
\text { Code }\end{array}$ & $\begin{array}{c}\text { Model-Code } \\
\mathbf{2 0 1 0}\end{array}$ & $\begin{array}{c}\text { BS-8110 } \\
\text { Code }\end{array}$ & $\begin{array}{c}\text { Euro-Code } \\
\mathbf{2}\end{array}$ & $\begin{array}{c}\text { ANFIS } \\
\text { ACI-14 } \\
\text { Code }\end{array}$ & $\begin{array}{c}\text { Model-Code } \\
\text { 2010 }\end{array}$ & $\begin{array}{c}\text { BS-8110 } \\
\text { Code }\end{array}$ & $\begin{array}{c}\text { Euro } \\
\text { Code 2 }\end{array}$ \\
\hline Training set & 164 & 1.0 & 0.88 & 1.10 & 1.01 & 1.45 & 0.11 & 0.30 & 0.16 & 0.14 & 0.20 \\
\hline Testing set & 43 & 1.01 & 0.84 & 1.07 & 0.98 & 1.42 & 0.13 & 0.26 & 0.15 & 0.13 & 0.19 \\
\hline
\end{tabular}

Table 3. Comparison summary of correlation $(R)$ and root mean square error (RMSE \%).

\begin{tabular}{cccccc}
\hline Type & Training & Correlation $(\boldsymbol{R})$ & \multicolumn{2}{c}{ RSME \% } \\
& Testing & All Data & Training & Testing \\
\hline ANFIS & 0.996 & 0.995 & 0.995 & 0.45 & 0.52 \\
ACI 318-14 Code & 0.927 & 0.952 & 0.927 & 2.06 & 2.05 \\
Model-Code-2010 & 0.986 & 0.992 & 0.986 & 0.93 & 0.72 \\
BS-8110-97 & 0.986 & 0.992 & 0.987 & 0.83 & 0.93 \\
Euro-Code 2 & 0.985 & 0.993 & 0.986 & 3.12 & 2.70 \\
\hline
\end{tabular}

\section{Parametric Studies}

After building and testing the ANFIS, and based on the comparison between the results obtained from the ANFIS model and the ACI 318-14 code, Model Code 2010, BS-8110, and Euro-Code 2, it could be concluded that the ANFIS was a suitable model in the prediction of the punching shear strength of two-way flat concrete slabs. The effect of each input parameter used to build the model was further investigated. The methodology of the parametric study was to vary one input parameter at a time, and the other input parameter were kept constant. Figures 19-23 show the predicted punching shear strength of a two-way flab slab as a function of each input variable. They show that the punching shear strength increased with an increase in the slab effective depth, concrete strength, and width of square loaded area. In general, the parametric tendencies of ANFIS agreed with the results from the ACI318-14 code, Model Code 2010, BS-8110, and Euro-Code 2, as shown in Figures 19-21. The punching shear strength increased with an increase in the reinforcement ratio: This result agreed with the other models, except for the ACI code, as shown in Figure 22. Finally, the sensitivity of the punching shear strength to the yield strength of reinforcement is presented in Figure 23, where it can be seen that all models except ANFIS showed no effect on the punching shear strength. Interestingly, ANFIS predicted a slight increase in shear strength with increasing yield strength, which was in agreement with some of the experimental results used to build the ANFIS model.

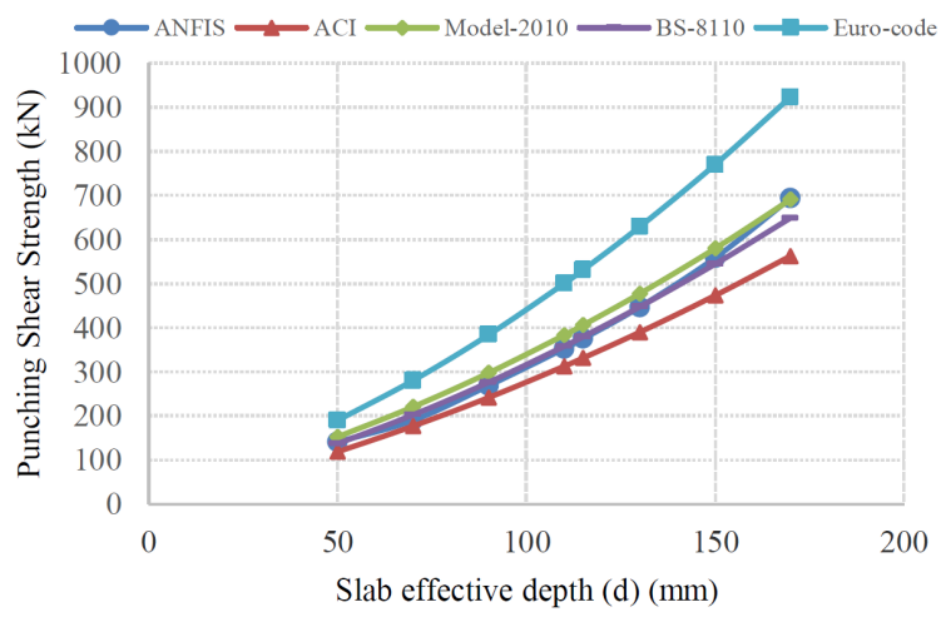

Figure 19. Effect of slab effective depth on the punching shear strength. 


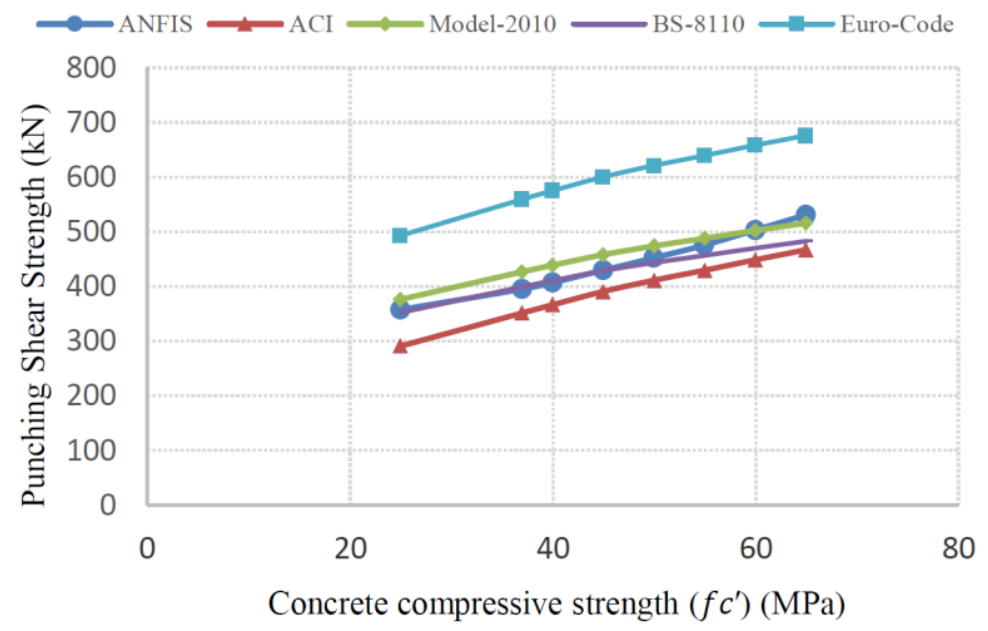

Figure 20. Effect of concrete compressive strength on the punching shear strength.

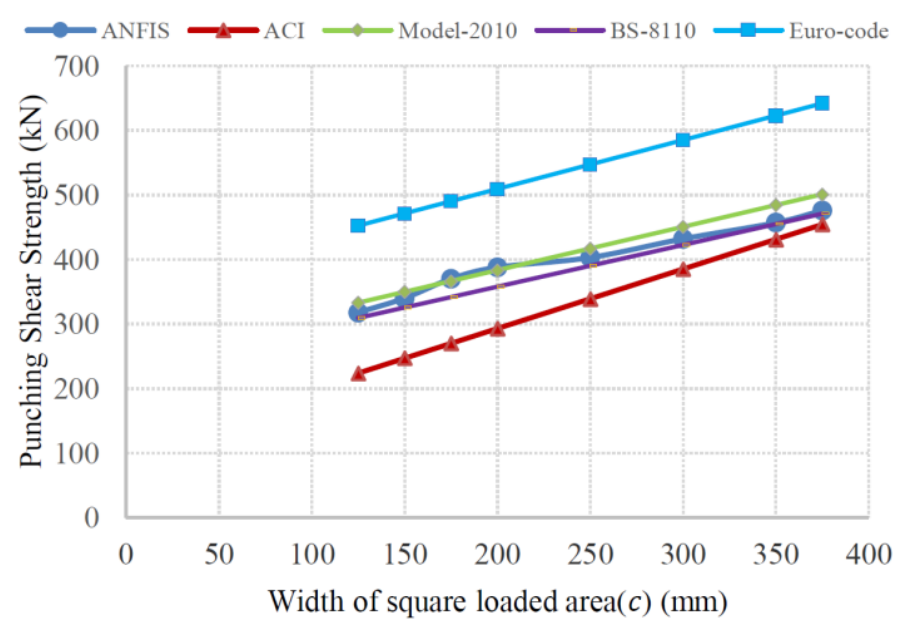

Figure 21. Effect of width of square loaded area on the punching shear strength.

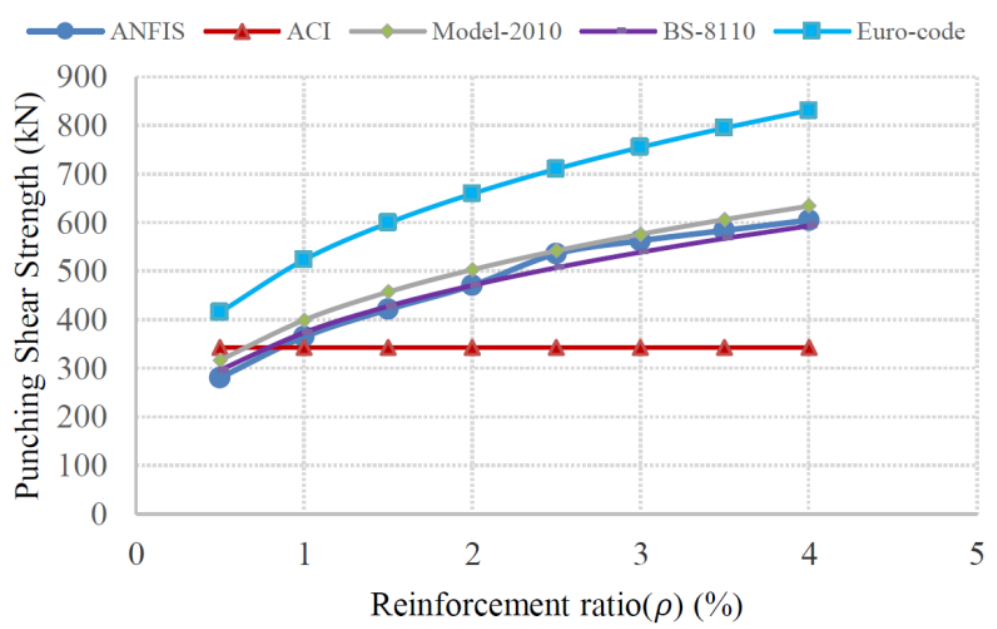

Figure 22. Effect of the reinforcement ratio on the punching shear strength. 


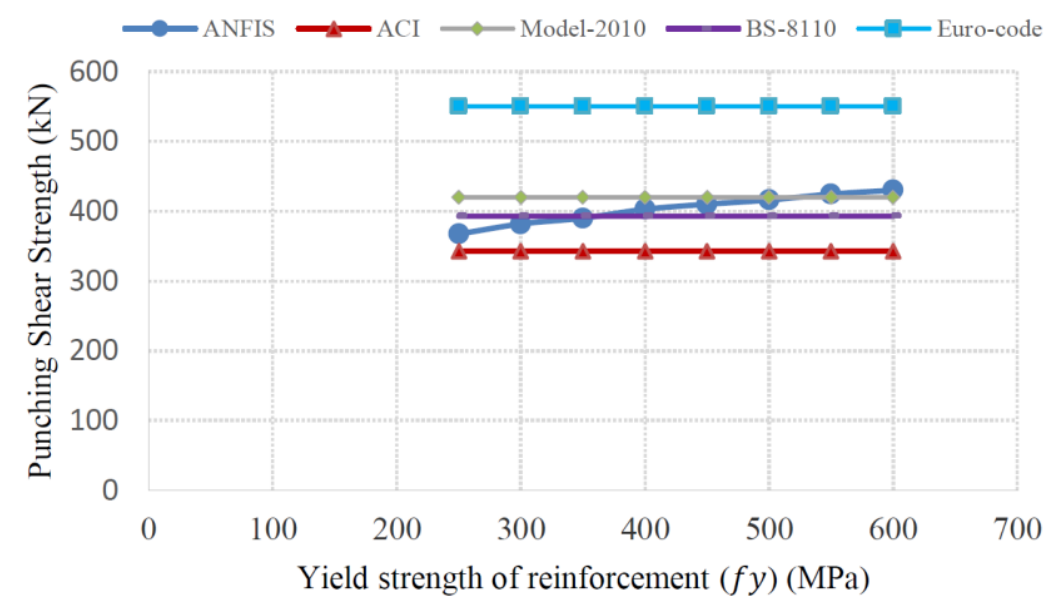

Figure 23. Effect of yield strength of reinforcement on the punching shear strength.

\section{Conclusions}

An adaptive neuro-fuzzy inference system (ANFIS)-based model was developed to predict the punching shear strength of two-way flat concrete slabs without shear reinforcement. A database of 207 test results available in the literature was used to train and test the model. The database covered a rather wide range of two-way flat slab parameters, including slab thickness, concrete strength, reinforcement ratio, yield strength of reinforcement, and width of square loaded area. Five variables were selected as inputs into the ANFIS, with punching shear strength as the output variable. Within the framework of ANFIS, different models may be developed using different learning algorithms with different membership functions and epochs. After experimenting with several of these different models, a model was chosen that had the best potential to predict experimental results. An ANFIS model with a hybrid learning algorithm, 200 epochs, and 10 Gaussian membership functions was selected and then tested. The results from the ANFIS model were compared to the experimental results and to those from the equations recommended in ACI 318-14, BS-8110-97, Model Code 2010, and Euro-Code 2. For these comparisons, the correlation coefficient ( $R$ ), the root mean square error (RMSE), and the average and standard deviations of the ratios of predicted $\left(V_{n i}\right)$ to experimental $\left(V_{n e}\right)$ punching shear strength were used as evaluation criteria. The values of $R$, RMSE, and average and standard deviations of $V n_{i} / V_{n e}$ for the training set were found to be $0.996,0.45,1.0$, and 0.11 , respectively, and for the testing set were $0.995,0.52,1.1$, and 0.13 , respectively, for the ANFIS model. This demonstrated that (i) the ANFIS model was capable of making highly reliable predictions of experimental results, (ii) the ANFIS model outperformed the equations recommended in four design codes currently used in practice, and (iii) the ANFIS model showed that it was a good tool for developing parametric studies to assess the influence of each parameter on the shear strength. In summary, the model developed in this study may serve as an economical, efficient, and reliable tool for the prediction of punching shear strength of flat concrete slabs.

Author Contributions: M.M.: Data curation, formal analysis, methodology, software, writing—original. A.M.: Writing-review and editing.

Funding: This research received no external funding.

Conflicts of Interest: The authors declare no conflicts of interest. 


\section{Appendix A}

Table A1. Experimental data used to construct the ANFIS.

\begin{tabular}{|c|c|c|c|c|c|c|c|}
\hline Test No. & $d$ & $f_{c}$ & $f_{y}$ & $\rho$ & $c$ & $V_{n}$ & Reference \\
\hline 1 & 118 & 25.2 & 332 & 1.16 & 254 & 365 & \multirow{19}{*}{ [43] } \\
\hline 2 & 118 & 36.8 & 332 & 1.16 & 254 & 351 & \\
\hline 3 & 118 & 20.3 & 332 & 1.16 & 254 & 356 & \\
\hline 4 & 114 & 19.5 & 321 & 2.5 & 254 & 400 & \\
\hline 5 & 114 & 37.4 & 321 & 2.5 & 254 & 467 & \\
\hline 6 & 114 & 27.9 & 321 & 2.5 & 254 & 512 & \\
\hline 7 & 114 & 22.6 & 321 & 3.74 & 254 & 445 & \\
\hline 8 & 114 & 26.5 & 321 & 3.74 & 254 & 534 & \\
\hline 9 & 114 & 34.5 & 321 & 3.74 & 254 & 547 & \\
\hline 10 & 118 & 26.1 & 332 & 1.18 & 356 & 400 & \\
\hline 11 & 114 & 25 & 321 & 3.74 & 356 & 498 & \\
\hline 12 & 121 & 26.2 & 294 & 0.55 & 356 & 236 & \\
\hline 13 & 114 & 14.2 & 324 & 0.48 & 254 & 178 & \\
\hline 14 & 114 & 47.6 & 321 & 0.48 & 254 & 200 & \\
\hline 15 & 114 & 43.9 & 341 & 2 & 254 & 505 & \\
\hline 16 & 114 & 50.5 & 325 & 3.02 & 254 & 578 & \\
\hline 17 & 118 & 29 & 332 & 1.16 & 254 & 356 & \\
\hline 18 & 114 & 27.8 & 321 & 2.5 & 356 & 534 & \\
\hline 19 & 114 & 47.7 & 303 & 1.01 & 254 & 334 & \\
\hline 20 & 114 & 27.5 & 400 & 1.38 & 305 & 394 & \multirow{12}{*}{ [44] } \\
\hline 21 & 114 & 23.2 & 400 & 1.06 & 254 & 390 & \\
\hline 22 & 114 & 22 & 400 & 1.03 & 254 & 356 & \\
\hline 23 & 114 & 23.8 & 400 & 1.13 & 254 & 334 & \\
\hline 24 & 114 & 25.3 & 400 & 1.02 & 254 & 379 & \\
\hline 25 & 114 & 35.1 & 400 & 1.13 & 254 & 374 & \\
\hline 26 & 114 & 20.4 & 400 & 1.13 & 254 & 312 & \\
\hline 27 & 114 & 24.2 & 400 & 1.06 & 203 & 379 & \\
\hline 28 & 114 & 23 & 400 & 1.5 & 305 & 433 & \\
\hline 29 & 114 & 26.5 & 400 & 1.38 & 152 & 312 & \\
\hline 30 & 114 & 24.4 & 400 & 1.06 & 254 & 393 & \\
\hline 31 & 114 & 22.1 & 400 & 1.06 & 203 & 343 & \\
\hline 32 & 51 & 21.1 & 386 & 1.1 & 152 & 79 & \multirow{19}{*}{ [41] } \\
\hline 33 & 51 & 15.5 & 386 & $\begin{array}{l}1.1 \\
1.1\end{array}$ & 203 & 93 & \\
\hline 34 & 50 & 27.2 & 386 & 2.2 & 203 & 133 & \\
\hline 35 & 51 & 22.9 & 386 & 2.2 & 254 & 152 & \\
\hline 36 & 51 & 23 & 386 & 1.1 & 305 & 114 & \\
\hline 37 & 51 & 27.7 & 386 & 1.1 & 356 & 139 & \\
\hline 38 & 51 & 25 & 386 & 2.2 & 356 & 184 & \\
\hline 39 & 51 & 24.9 & 386 & 1.1 & 406 & 145 & \\
\hline 40 & 50 & 24.6 & 386 & 2.2 & 406 & 185 & \\
\hline 41 & 50 & $\begin{array}{c}27.0 \\
27\end{array}$ & 386 & $\begin{array}{l}2.2 \\
1.1\end{array}$ & 152 & 102 & \\
\hline $\begin{array}{l}71 \\
42\end{array}$ & 50 & 28.5 & 386 & $\begin{array}{l}1.1 \\
1.1\end{array}$ & 102 & 86 & \\
\hline 43 & 50 & 24.9 & 386 & $\begin{array}{l}1.1 \\
2.2\end{array}$ & 102 & $\begin{array}{c}00 \\
102\end{array}$ & \\
\hline 44 & 50 & 53.8 & 386 & 2.2 & 152 & 172 & \\
\hline 45 & 50 & 21.1 & 386 & 1.1 & 152 & 99 & \\
\hline 46 & 50 & 17 & 386 & 2.2 & 152 & 105 & \\
\hline 47 & 51 & 18 & 336 & 2.2 & 152 & 99 & \\
\hline 48 & 51 & 23.3 & 336 & 1.1 & 254 & 109 & \\
\hline 49 & 50 & 26.4 & 386 & 2.2 & 305 & 159 & \\
\hline 50 & 50 & 20 & 386 & 1.1 & 152 & 112 & \\
\hline
\end{tabular}


Table A1. Cont.

\begin{tabular}{|c|c|c|c|c|c|c|c|}
\hline Test No. & $d$ & $f_{c}$ & $f_{y}$ & $\rho$ & $c$ & $V_{n}$ & Reference \\
\hline 51 & 100 & 35.7 & 706 & 0.8 & 125 & 216 & \multirow{8}{*}{ [42] } \\
\hline 52 & 99 & 28.6 & 701 & 0.81 & 125 & 194 & \\
\hline 53 & 199 & 28.6 & 670 & 0.89 & 250 & 600 & \\
\hline 54 & 200 & 30.3 & 657 & 0.8 & 250 & 603 & \\
\hline 55 & 98 & 33.3 & 720 & 0.35 & 125 & 145 & \\
\hline 56 & 99 & 31.4 & 712 & 0.34 & 125 & 148 & \\
\hline 57 & 200 & 31.7 & 668 & 0.34 & 250 & 489 & \\
\hline 58 & 197 & 30.2 & 664 & 0.35 & 250 & 444 & \\
\hline 59 & 77 & 23.3 & 500 & 1.2 & 200 & 176 & \multirow{10}{*}{ [45] } \\
\hline 60 & 77 & 33.4 & 500 & 0.92 & 200 & 194 & \\
\hline 61 & 79 & 21.7 & 480 & 0.75 & 200 & 165 & \\
\hline 62 & 79 & 31.2 & 480 & 0.8 & 200 & 186 & \\
\hline 63 & 200 & 36.3 & 530 & 0.98 & 250 & 825 & \\
\hline 64 & 128 & 34.5 & 485 & 0.98 & 160 & 390 & \\
\hline 65 & 64 & 34.5 & 480 & 0.98 & 80 & 117 & \\
\hline 66 & 128 & 35.7 & 485 & 0.98 & 160 & 365 & \\
\hline 67 & 64 & 35.7 & 480 & 0.98 & 80 & 105 & \\
\hline 68 & 64 & 37.8 & 480 & 0.98 & 80 & 105 & \\
\hline 69 & 41 & 31.5 & 530 & 0.42 & 100 & 36 & \multirow{27}{*}{ [46] } \\
\hline 70 & 41 & 31.5 & 530 & 0.69 & 100 & 49 & \\
\hline 71 & 41 & 36.2 & 530 & 0.82 & 100 & 56 & \\
\hline 72 & 41 & 36.2 & 530 & 1.03 & 100 & 66 & \\
\hline 73 & 41 & 30.4 & 530 & 1.16 & 100 & 71 & \\
\hline 74 & 41 & 30.4 & 530 & 1.29 & 100 & 71 & \\
\hline 75 & 41 & 30.4 & 530 & 1.45 & 100 & 79 & \\
\hline 76 & 41 & 30.6 & 530 & 0.52 & 100 & 44 & \\
\hline 77 & 41 & 30.6 & 530 & 0.8 & 100 & 55 & \\
\hline 78 & 41 & 35.3 & 530 & 0.6 & 100 & 49 & \\
\hline 79 & 41 & 35.3 & 530 & 0.69 & 100 & 52 & \\
\hline 80 & 41 & 35.3 & 530 & 1.99 & 100 & 85 & \\
\hline 81 & 47 & 29.4 & 530 & 0.44 & 100 & 45 & \\
\hline 82 & 47 & 29.4 & 530 & 0.69 & 100 & 66 & \\
\hline 83 & 47 & 31.7 & 530 & 1.99 & 100 & 97 & \\
\hline 84 & 35 & 39.6 & 530 & 0.42 & 100 & 29 & \\
\hline 85 & 35 & 39.6 & 530 & 0.69 & 100 & 38 & \\
\hline 86 & 35 & 31.7 & 530 & 1.99 & 100 & 73 & \\
\hline 87 & 54 & 28.3 & 530 & 0.42 & 100 & 63 & \\
\hline 88 & 54 & 33.5 & 530 & 0.69 & 100 & 88 & \\
\hline 89 & 41 & 31.5 & 530 & 0.56 & 100 & 49 & \\
\hline 90 & 41 & 36.2 & 530 & 0.88 & 100 & 57 & \\
\hline 91 & 41 & 30.6 & 530 & 1.11 & 100 & 67 & \\
\hline 92 & 47 & 29.4 & 530 & 1.29 & 100 & 90 & \\
\hline 93 & 35 & 39.6 & 530 & 1.29 & 100 & 57 & \\
\hline 94 & 54 & 33.5 & 530 & 1.29 & 100 & 124 & \\
\hline 95 & 54 & 28.3 & 530 & 1.99 & 100 & 126 & \\
\hline
\end{tabular}


Table A1. Cont.

\begin{tabular}{|c|c|c|c|c|c|c|c|}
\hline Test No. & $d$ & $f_{c}$ & $f_{y}$ & $\rho$ & $c$ & $V_{n}$ & Reference \\
\hline 96 & 76 & 24.1 & 430 & 2.05 & 102 & 129 & \multirow{18}{*}{ [47] } \\
\hline 97 & 76 & 22.6 & 430 & 2.05 & 102 & 136 & \\
\hline 98 & 113 & 22.6 & 430 & 2.14 & 152 & 311 & \\
\hline 99 & 113 & 24.8 & 430 & 2.14 & 203 & 357 & \\
\hline 100 & 122 & 24.8 & 430 & 0.66 & 203 & 271 & \\
\hline 101 & 73 & 25 & 430 & 5.01 & 152 & 202 & \\
\hline 102 & 86 & 23.2 & 430 & 0.45 & 152 & 107 & \\
\hline 103 & 81 & 25.5 & 430 & 1.47 & 102 & 121 & \\
\hline 104 & 123 & 22.1 & 430 & 0.47 & 203 & 271 & \\
\hline 105 & 113 & 15.1 & 430 & 2.14 & 203 & 278 & \\
\hline 106 & 81 & 14.5 & 430 & 1.47 & 152 & 108 & \\
\hline 107 & 73 & 52.1 & 430 & 5.01 & 203 & 323 & \\
\hline 108 & 81 & 52.1 & 430 & 1.47 & 152 & 243 & \\
\hline 109 & 76 & 24.6 & 430 & 2.05 & 102 & 129 & \\
\hline 110 & 81 & 25 & 430 & 1.47 & 152 & 160 & \\
\hline 111 & 122 & 16.1 & 430 & 0.66 & 203 & 230 & \\
\hline 112 & 122 & 52.1 & 430 & 0.66 & 203 & 306 & \\
\hline 113 & 86 & 52.1 & 430 & 0.45 & 152 & 148 & \\
\hline 114 & 95 & 42 & 490 & 1.47 & 150 & 320 & \multirow{15}{*}{ [40] } \\
\hline 115 & 95 & 67 & 490 & 0.49 & 150 & 178 & \\
\hline 116 & 95 & 70 & 490 & 0.84 & 150 & 249 & \\
\hline 117 & 95 & 69 & 490 & 1.47 & 150 & 356 & \\
\hline 118 & 90 & 66 & 490 & 2.37 & 150 & 418 & \\
\hline 119 & 120 & 30 & 490 & 0.94 & 150 & 396 & \\
\hline 120 & 125 & 68 & 490 & 0.64 & 150 & 365 & \\
\hline 121 & 120 & 69 & 490 & 1.11 & 150 & 436 & \\
\hline 122 & 120 & 74 & 490 & 1.61 & 150 & 543 & \\
\hline 123 & 120 & 80 & 490 & 2.33 & 150 & 645 & \\
\hline 124 & 70 & 75 & 490 & 1.52 & 150 & 258 & \\
\hline 125 & 70 & 68 & 490 & 1.87 & 150 & 267 & \\
\hline 126 & 95 & 72 & 490 & 1.47 & 220 & 498 & \\
\hline 127 & 95 & 74 & 490 & 1.19 & 150 & 356 & \\
\hline 128 & 120 & 70 & 490 & 0.94 & 150 & 489 & \\
\hline 129 & 70 & 70 & 490 & 0.95 & 150 & 196 & \\
\hline 130 & 95 & 71 & 490 & 1.47 & 300 & 560 & \\
\hline 131 & 275 & 64 & 500 & 1.49 & 200 & 2050 & \multirow{13}{*}{ [48] } \\
\hline 132 & 275 & 112 & 500 & 1.49 & 200 & 2450 & \\
\hline 133 & 275 & 90 & 500 & 2.55 & 200 & 2400 & \\
\hline 134 & 200 & 88 & 500 & 1.75 & 150 & 1100 & \\
\hline 135 & 200 & 87 & 500 & 1.75 & 150 & 1300 & \\
\hline 136 & 200 & 119 & 500 & 1.75 & 150 & 1400 & \\
\hline 137 & 275 & 84 & 500 & 1.49 & 200 & 2250 & \\
\hline 138 & 200 & 70 & 500 & 1.75 & 150 & 1200 & \\
\hline 139 & 200 & 90 & 500 & 2.62 & 150 & 1450 & \\
\hline 140 & 200 & 98 & 500 & 2.62 & 150 & 1450 & \\
\hline 141 & 200 & 80 & 500 & 2.62 & 150 & 1250 & \\
\hline 142 & 200 & 108 & 500 & 2.62 & 150 & 1550 & \\
\hline 143 & 88 & 85 & 500 & 1.4 & 100 & 330 & \\
\hline 144 & 200 & 90 & 643 & 0.8 & 250 & 965 & \multirow{7}{*}{ [50] } \\
\hline 145 & 200 & 91 & 627 & 0.8 & 250 & 1021 & \\
\hline 146 & 200 & 92 & 596 & 1.19 & 250 & 1041 & \\
\hline 147 & 201 & 109 & 633 & 0.6 & 250 & 960 & \\
\hline 148 & 202 & 84 & 634 & 0.33 & 250 & 565 & \\
\hline 149 & 194 & 86 & 620 & 0.82 & 250 & 889 & \\
\hline 150 & 198 & 95 & 631 & $\begin{array}{c}0.8 \\
0.8\end{array}$ & 250 & 944 & \\
\hline
\end{tabular}


Table A1. Cont.

\begin{tabular}{|c|c|c|c|c|c|c|c|}
\hline Test No. & $d$ & $f_{c}$ & $f_{y}$ & $\rho$ & $c$ & $V_{n}$ & Reference \\
\hline 151 & 98 & 88.2 & 550 & 0.58 & 150 & 224 & \multirow{15}{*}{ [49] } \\
\hline 152 & 98 & 56.2 & 550 & 0.58 & 150 & 212 & \\
\hline 153 & 98 & 26.9 & 550 & 0.58 & 150 & 169 & \\
\hline 154 & 98 & 101.8 & 550 & 0.58 & 150 & 233 & \\
\hline 155 & 98 & 60.4 & 550 & 1.28 & 150 & 319 & \\
\hline 156 & 98 & 43.4 & 550 & 1.28 & 150 & 297 & \\
\hline 157 & 98 & 98.4 & 550 & 1.28 & 150 & 362 & \\
\hline 158 & 98 & 41.9 & 650 & 1.28 & 150 & 286 & \\
\hline 159 & 98 & 84.2 & 650 & 1.28 & 150 & 405 & \\
\hline 160 & 100 & 56.4 & 650 & 0.87 & 150 & 341 & \\
\hline 161 & 100 & 37.6 & 650 & 1.27 & 150 & 294 & \\
\hline 162 & 98 & 58.7 & 550 & 0.58 & 150 & 233 & \\
\hline 163 & 98 & 60.8 & 550 & 1.28 & 150 & 341 & \\
\hline 164 & 100 & 32.9 & 650 & 1.27 & 150 & 244 & \\
\hline 165 & 102 & 33.7 & 650 & 1.03 & 150 & 227 & \\
\hline 166 & 100 & 39.4 & 488 & 0.97 & 200 & 330 & \multirow{6}{*}{ [51] } \\
\hline 167 & 150 & 39.4 & 465 & 0.9 & 200 & 583 & \\
\hline 168 & 200 & 39.4 & 465 & 0.83 & 200 & 904 & \\
\hline 169 & 300 & 39.4 & 468 & 0.76 & 200 & 1381 & \\
\hline 170 & 400 & 39.4 & 433 & 0.76 & 300 & 2224 & \\
\hline 171 & 500 & 39.4 & 433 & 0.76 & 300 & 2681 & \\
\hline 172 & 210 & 27.6 & 400 & 1.5 & 260 & 1024 & \multirow{9}{*}{ [52] } \\
\hline 173 & 210 & 28.5 & 400 & 0.25 & 260 & 445 & \\
\hline 174 & 464 & 32.4 & 400 & 0.33 & 520 & 2153 & \\
\hline 175 & 210 & 32.2 & 400 & 0.25 & 260 & 408 & \\
\hline 176 & 210 & 29.3 & 400 & 0.33 & 260 & 550 & \\
\hline 177 & 96 & 34.7 & 400 & 1.5 & 130 & 236 & \\
\hline 178 & 100 & 34.7 & 400 & 0.75 & 130 & 243 & \\
\hline 179 & 102 & 34.7 & 400 & 0.25 & 130 & 118 & \\
\hline 180 & 210 & 40.5 & 400 & 0.25 & 260 & 439 & \\
\hline 181 & 102 & 34.7 & 400 & 0.33 & 130 & 141 & \multirow{5}{*}{ [53] } \\
\hline 182 & 210 & 28.5 & 400 & 0.33 & 260 & 540 & \\
\hline 183 & 100 & 24 & 718 & 0.8 & 250 & 270 & \\
\hline 184 & 100 & 24.4 & 718 & 0.8 & 250 & 250 & \\
\hline 185 & 125 & 27.2 & 718 & 0.64 & 150 & 265 & \\
\hline 186 & 124 & 33.1 & 488 & 1.54 & 250 & 483 & \multirow{3}{*}{ [54] } \\
\hline 187 & 190 & 33.5 & 531 & 1.3 & 300 & 825 & \\
\hline 188 & 260 & 31 & 524 & 1.1 & 350 & 1046 & \\
\hline 189 & 158 & 35 & 490 & 2.17 & 250 & 678 & \multirow{8}{*}{ [55] } \\
\hline 190 & 128 & 70 & 490 & 2.68 & 250 & 801 & \\
\hline 191 & 158 & 66.7 & 490 & 1.67 & 250 & 802 & \\
\hline 192 & 113 & 70 & 490 & 1.88 & 250 & 480 & \\
\hline 193 & 163 & 33 & 490 & 0.52 & 250 & 479 & \\
\hline 194 & 138 & 68.5 & 490 & 2.48 & 250 & 788 & \\
\hline 195 & 158 & 61.2 & 490 & 1.13 & 250 & 811 & \\
\hline 196 & 105 & 34 & 490 & 0.4 & 250 & 228 & \\
\hline 197 & 105 & 44.7 & 400 & 0.45 & 250 & 219 & \multirow{11}{*}{ [56] } \\
\hline 198 & 183 & 35 & 400 & 0.35 & 250 & 438 & \\
\hline 199 & 183 & 70 & 400 & 0.35 & 250 & 574 & \\
\hline 200 & 218 & 40 & 400 & 0.73 & 250 & 882 & \\
\hline 201 & 220 & 76 & 400 & 0.43 & 250 & 886 & \\
\hline 202 & 268 & 75 & 400 & 1.13 & 400 & 1721 & \\
\hline 203 & 263 & 65 & 400 & 1.44 & 400 & 2090 & \\
\hline 204 & 313 & 40 & 400 & 1.57 & 400 & 2234 & \\
\hline 205 & 313 & 60 & 400 & 1.57 & 400 & 2513 & \\
\hline 206 & 153 & 50.2 & 400 & 0.55 & 250 & 491 & \\
\hline 207 & 218 & 64.7 & 400 & 0.73 & 250 & 1023 & \\
\hline
\end{tabular}




\section{References}

1. Menetrey, P. Synthesis of punching failure in reinforced concrete. Cem. Concr. Compos. 2002, 24, 497-507. [CrossRef]

2. Abbasi, M.; Baluch, M.H.; Azad, A.K.; Abdelrahman, H. Nonlinear finite element modelling of failure modes in RC slabs. Comp. Struct. 1992, 42, 815-823. [CrossRef]

3. Theodorakopoulos, D.; Swamy, R. Ultimate punching shear strength analysis of slab-column connections. Cem. Concr. Compos. 2002, 24, 509-521. [CrossRef]

4. Metwally, I.M.; Issa, M.S.; El-Betar, S.A. Punching shear resistance of normal and high strength reinforced concrete flat slabs. Civ. Eng. Res. Mag. 2008, 30, 982-1004.

5. Micallef, K.; Sagaseta, J.; Ruiz, M.F.; Muttoni, A. Assessing punching shear failure in reinforced concrete flat slabs subjected to localised impact loading. Int. J. Impact Eng. 2014, 71, 17-33. [CrossRef]

6. ACI. Building Code Requirements for Reinforced Concrete; American Concrete Institute: Farmington Hills, MI, USA, 2014.

7. BS. Structural Use of Concrete. Part I: Code of Practice for Design and Construction; British Standards Institution: London, UK, 1997.

8. FIB, M.C. Model Code 2010-Final Draft, Vol, 1; Bulletins: Lausanne, Switzerland, 2010.

9. De Normalisation, C.E. Eurocode 2: Design of Concrete Structures-Part 1-1: General Rules and Rules for Buildings; European Committee for Standardization: Brussels, Belgium, 2004.

10. Shoorehdeli, M.A.; Teshnehlab, M.; Sedigh, A.K. Identification using ANFIS with intelligent hybrid stable learning algorithm approaches. Neural Comput. Appl. 2009, 18, 157-174. [CrossRef]

11. Kasperkiewicz, J.; Racz, J.; Dubrawski, A. HPC strength prediction using artificial neural network. J. Comput. Civ. Eng. 1995, 9, 279-284. [CrossRef]

12. Takagi, T.; Sugeno, M. Fuzzy identification of systems and its applications to modeling and control. IEEE Trans. Syst. Man Cybern. 1985, 1, 116-132. [CrossRef]

13. Topçu, İ.B.; Sarıdemir, M. Prediction of rubberized concrete properties using artificial neural network and fuzzy logic. Constr. Build. Mater. 2008, 22, 532-540. [CrossRef]

14. Bilgehan, M. Comparison of ANFIS and NN models-With a study in critical buckling load estimation. Appl. Soft Comput. 2011, 11, 3779-3791. [CrossRef]

15. Tesfamariam, S.; Najjaran, H. Adaptive network-fuzzy inferencing to estimate concrete strength using mix design. J. Mater. Civ. Eng. 2007, 19, 550-560. [CrossRef]

16. Akbulut, S.; Hasiloglu, A.S.; Pamukcu, S. Data generation for shear modulus and damping ratio in reinforced sands using adaptive neuro-fuzzy inference system. Soil Dyn. Earthq. Eng. 2004, 24, 805-814. [CrossRef]

17. Inan, G.; Göktepe, A.B.; Ramyar, K.; Sezer, A. Prediction of sulfate expansion of PC mortar using adaptive neuro-fuzzy methodology. Build. Environ. 2007, 42, 1264-1269. [CrossRef]

18. Fonseca, E.T.; g da s Vellasco, P.C.; Vellasco, M.M.B.R.; de Andrade, S.A.L. A neuro-fuzzy evaluation of steel beams patch load behaviour. Adv. Eng. Softw. 2008, 39, 558-572. [CrossRef]

19. Wang, Y.-M.; Elhag, T.M. An adaptive neuro-fuzzy inference system for bridge risk assessment. Expert Syst. Appl. 2008, 34, 3099-3106. [CrossRef]

20. Bateni, S.; Jeng, D.-S. Estimation of pile group scour using adaptive neuro-fuzzy approach. Ocean Eng. 2007, 34, 1344-1354. [CrossRef]

21. Mashrei, M.A. Prediction of the Shear Strength of Concrete Beams Reinforced with Fiber Reinforced Polymer Bars Using Artificial Neural Networks Model. Thi-Qar Univ. J. Eng. Sci. 2011, 2, 45-63.

22. Bilgehan, M.; Kurtoğlu, A.E. ANFIS-based prediction of moment capacity of reinforced concrete slabs exposed to fire. Neural Comput. Appl. 2016, 27, 869-881. [CrossRef]

23. Mansouri, I.; Kisi, O.; Sadeghian, P.; Lee, C.-H.; Hu, J.W. Prediction of ultimate strain and strength of FRP-confined concrete cylinders using soft computing methods. Appl. Sci. 2017, 7, 751. [CrossRef]

24. Naderpour, H.; Poursaeidi, O.; Ahmadi, M. Shear Resistance Prediction of Concrete Beams Reinforced by FRP Bars Using Artificial Neural Networks. Measurement 2018. [CrossRef]

25. Basarir, H.; Bin, H.; Fourie, A.; Karrech, A.; Elchalakani, M. An adaptive neuro fuzzy inference system to model the uniaxial compressive strength of cemented hydraulic backfill. Min. Miner. Depos. 2018, 12, 1-12. [CrossRef] 
26. Dönmez, A.; Bažant, Z.P. Size effect on punching strength of reinforced concrete slabs with and without shear reinforcement. ACI Struct. J. 2017, 114, 875. [CrossRef]

27. Shehata, I.A. Simplified model for estimating the punching resistance of reinforced corete slabs. Mater. Struct. 1990, 23, 364-371. [CrossRef]

28. Regan, P.E. Behaviour of Reinforced Concrete Flat Slabs; Construction Inudstry Research and Information Association: London, UK, 1981.

29. Gardner, N. Size Effect on Punching Strength of Reinforced Concrete Slabs with and without Shear Reinforcement. ACI Struct. J. 2018, 115, 897-899.

30. Bazant, Z.P.; Kim, J.K. Size effect in shear failure of longitudinally reinforced beams. J. Am. Concr. Inst. 1984, 81, 456-468.

31. Demirkaya, S. Deformation analysis of an arch dam using ANFIS. In Proceedings of the Second International Workshop on Application of Artificial Intelligence and Innovations in Engineering Geodesy, Braunschweig, Germany, June 2010.

32. Chang, F.J.; Chang, Y.T. Adaptive neuro-fuzzy inference system for prediction of water level in reservoir. Adv. Water Resour. 2006, 29, 1-10. [CrossRef]

33. Xu, J.; Wang, X.L. Prediction of Concrete Strength Using Fuzzy Neural Networks. Adv. Mater. Res. 2011, 243, 6121-6126. [CrossRef]

34. Jang, J.S. ANFIS: Adaptive-network-based fuzzy inference system. IEEE Trans. Syst. Man Cybern. 1993, 23, 665-685. [CrossRef]

35. Mamdani, E.H. Application of fuzzy algorithms for control of simple dynamic plant. Proc. Electr. Eng. 1974, 121. [CrossRef]

36. Sugeno, M.; Tanaka, K. Successive identification of a fuzzy model and its applications to prediction of a complex system. Fuzzy Sets Syst. 1991, 42, 315-334. [CrossRef]

37. Sugeno, M.; Kang, G. Structure identification of fuzzy model. Fuzzy Sets Syst. 1988, 28, 15-33. [CrossRef]

38. Zadeh, L.A. Information and control. Fuzzy Sets 1965, 8, 338-353.

39. MATLAB, V. 8.1. 0.604 (R2013a); MathWorks: Natick, MA, USA, 2013.

40. Marzouk, H.; Hussein, A. Experimental investigation on the behavior of high-strength concrete slabs. ACI Struct. J. 1991, 88, 701-713.

41. Mowrer, R.; Vanderbilt, M. Shear strength of lightweight aggregate reinforced concrete flat plates. J. Am. Concr. Inst. 1967, 64, 722-729.

42. Kinnunen, S.; Nylander, H.; Tolf, P. Investigations on Punching at the Division of Building Statics and Structural Engineering. Nordisk Betong 1978, 3, 25-27.

43. Elstner, R.C.; Hognestad, E. Shearing strength of reinforced concrete slabs. J. Proc. 1956, 53, $29-58$.

44. Moe, J. Shearing Strength of Reinforced Concrete Slabs and Footings under Concentrated Loads; Portland Cement Association, Research and Development Laboratories: Chicago, IL, USA, 1961.

45. Regan, P.; Walker, P.; Zakaria, K. Tests of Reinforced Concrete Flat Slabs; CIRIA Project RP; Polytechnic of Central: London, UK, 1979; 220p.

46. Rankin, G.; Long, A. Predicting the Punching Strength of Conventional Slab-Column Specimens. Proc. Inst. Civ. Eng. 1987, 82, 327-346. [CrossRef]

47. Gardner, N. Relationship of the punching shear capacity of reinforced concrete slabs with concrete strength. Struct. J. 1990, 87, 66-71.

48. Tomaszewicz, A. Punching Shear Capacity of Reinforced Concrete Slabs; Trondheim SINTEF: Trondheim, Norway, 1993; 36p.

49. Ramdane, K. Punching shear of high performance concrete slabs. In Proceedings of the Fourth International Symposium on Utilization of High-Strength/High Performance Concrete, Paris, France, 29-31 May 1996.

50. Hallgren, M. Punching Shear Capacity of Reinforced High Strength Concrete Slabs; KTH Byggvetenskap: Stockholm, Sweden, 1996.

51. Kevin, K. Influence of Size on Punching Shear Strength of Concrete Slabs; McGill University: Montreal, QC, Canada, 2000; p. 92.

52. Guandalini, S.; Muttoni, A. Symmetrical Punching Tests on Slabs without Transverse Reinforcement; Test Report; de Lausanne Institut: Lausanne, Switzerland, 2004. 
53. Sundquist, H.; Kinnunen, S. The Effect of Column Head and Drop Panels on the Punching Capacity of Flat Slabs; Bulletin No. 82; Department of Civil and Architectural Engineering, Royal Institute of Technology: Stockholm, Sweden, 2004.

54. Birkle, G.; Dilger, W.H. Influence of slab thickness on punching shear strength. ACI Struct. J. 2008, 105, 180-188.

55. Marzouk, H.; Hossin, M. Crack Analysis of Reinforced Concrete Two-Way Slabs; Research Report; Faculty of Engineering and Applied Science, Memorial University of Newfoundland: St. John's, NL, Canada, 2007.

56. Marzouk, R.; Rizk, E. Punching Analysis of Reinforced Concrete Two-Way Slabs; Research Report RCS01; Faculty of Engineering and Applied Science, Memorial University of Newfoundland: St. John's, NL, Canada, 2009.

57. Chiu, S.L. Fuzzy model identification based on cluster estimation. J. Int. Fuzzy Syst. 1994, 2, 267-278.

58. Mashrei, M.A.; Abdulrazzaq, N.; Abdalla, T.Y.; Rahman, M.S. Neural networks model and adaptive neuro-fuzzy inference system for predicting the moment capacity of ferrocement members. Eng. Struct. 2010, 32, 1723-1734. [CrossRef]

(C) 2019 by the authors. Licensee MDPI, Basel, Switzerland. This article is an open access article distributed under the terms and conditions of the Creative Commons Attribution (CC BY) license (http:/ / creativecommons.org/licenses/by/4.0/). 